\title{
EVALUATION PROGRAM OF PREGNANCY CLASS IN MOJOGEDANG II HEALTH CENTER IN KARANGANYAR, CENTRAL JAVA
}

\author{
Kristuti Catur Sumarah'), Gita Kostania²), Emy Suryani3) \\ ${ }^{1)}$ Masters Program in Public Health, Universitas Sebelas Maret \\ ${ }^{2)}$ Diploma IV of Midwivery, Health Polytechnics, Ministry of Health Surakarta
}

\begin{abstract}
Background: The importance of parenting education programmes stems from the fact that they empower the woman and/or her partner at the time when they are most vulnerable: during pregnancy and the postnatal period. The main aims of antenatal class is to promote healthy practices, minimize excessive anxiety and prevent or minimize the discomforts of pregnancy and labor. So that, antenatal class assessment is needed to evaluate current quality of these programmes. This study aimed to investigate the evaluation program of pregnancy class.

Subjects and Method: This was a qualitative study conducted at Mojogedang II health center, Karanganyar, Central Java, in March 2017. Head of health center, midwife, and cadres were purposively selected as the key informants. Research problem was evaluation of pre-implementation of pregnancy class. The data were collected by in-depth interview and observation.

Results: Pre-implementation of antenatal class at Mojogedang II health center in Karanganyar, in 2016, is in accordance with the World Health Organization recommendations. Monitoring, evaluation and reporting activities are in accordance with the provisions of antenatal class guidebook. The involvement of health workers and cadres is quite high, but the support of husbands and parents is still low.

Conclusion: $\mathrm{Tt}$ is necessary to increase the participation of husbands and families in prenatal class.
\end{abstract}

Keywords: evaluation program, antenatal class, maternal health

\section{Correspondence:}

Kristuti Catur Sumarah. Masters Program in Public Health, Universitas Sebelas Maret. Jl. Ir. Sutami 36A, Surakarta 57126, Central Java. Email: skristuticatur@gmail.com. Mobile +6182314289595 . 